Research Article

\title{
The Use of Teacher's Joke Increases Students' Involvement inside Classroom
}

\author{
Nor Azizah Ahmad ${ }^{1}$, Suriani Mohamed ${ }^{2}$, Khairul Anuar Hasnan ${ }^{3}$, Norhayati Ali ${ }^{4}$, Farah Najwa \\ Ahmad Puad ${ }^{5}$
}

\author{
Faculty of Technical and Vocational, Universiti Pendidikan Sultan Idris, Perak, Malaysia
}

*Corresponding author: Nor Azizah Ahmad ${ }^{1}$

\begin{abstract}
The purpose of the study was to identify the type of joke and the frequency of joke $s$ used inside the classroom. In addition, studies have also been conducted to examine the involvement of students when element of joke is applied in the classroom and determine the relationship between joke frequency and students' involvement. This study is a quantitative type of survey. The instrument used is a set of four parts questionnaire. The populations studied involved secondary school teachers in Muallim District while the samples studied was selected using simple random sampling. The number of samples involved is $\mathbf{2 6 9}$ people. The findings show that the majority of teachers in Muallim District use jokes while teaching in the classroom. Among the jokes applied are jests, cynics, funny face expressions and funny stories $(n=$ 92, Percentage $=34.20 \%)$. However, the joke frequency inside the classroom is moderate $(n=164$, Percentage $=61.00 \%)$. Furthermore, the findings show that the use of joke element can make students to feel more at ease with the teacher when speaking or interacting $(n=115$, Percentage $=38.50 \%)$. Correlation analysis indicated that there was a link between frequency of joke used and student's involvement when joke was applied in the classroom $(r=0.42, p<0.05)$. It can be concluded that the application of joke element is commendable inside the classroom, however, the joke frequency needs to be controlled as it can disrupt the students focus on learning.
\end{abstract}

Keywords: joke element; classroom; secondary school; correlation analysis.

\section{Introduction}

Each student has different attitudes and motivations towards the acceptance of teaching and learning taught by the teacher. Hence, teachers are indirectly playing an important role in identifying the learning style of students taught inside the classroom. This is because the students learning style is different and varies among each other where there are students who are willing to receive instruction from the teacher and some can learn better when given the freedom to conduct learning activities. Additionally, there are also students who need guidance and stronger support from teachers and others who are more self-reliant and have a strong self-concept. According to Sternberg (2003), the main reason why a student is not fully learning in the classroom is because teachers often behave flippancyly in detecting student's learning style because they are not so keen or unwisely handling the situation. Hence, teachers must play an important role in addressing this problem by diversifying teaching and learning strategies, teaching methods and an effective conveyance planning.

Jokes or philanthropy can be defined as the ability of an individual (human), object, situation or word to bring in a happy or entertained feeling. Kecindan is a root word derived from the Minangkabau language. Based on the study conducted by Frymier et al. (2008) jokes in the classroom help facilitate interaction between teachers and students and enhance the effectiveness of teaching and learning. Meanwhile, according to Desberg \& Others (1981), kecindan atmosphere is said able to be immediately reduce the tense situation of students inside the classroom. In addition, the learning environment exists during the joke uttered is also said able to improve the performance of students and teachers inside the classroom. This is because the fun-filled joke creates a healthy and fun learning environment. Fun learning environment is one of the concepts introduced by the government in the Ministry of Education (MOE) in improving the effectiveness of teaching and learning processes in the classroom. This concept is introduced to school teachers to bring fun learning environments to school. Thus, joke is one of the methods that teachers can use in school to create a fun environment. In this regard, the use of joke elements in learning and teaching also needs to be constricted where the joke elements used in learning and teaching are not excessively used but only when the element is related to the content of the lesson to be learned on that day. This is to prevent students from being overwhelmed by jokes and inappropriate jokes would have a bad effect on the student.

In addition, according to Paterson (2006) jokes need to be used as appropriately as possible because in that study, he found that jokes can help overcome some of the problems that arise in school. One of the problems that can be solved is to improve the attitude of students' lack of interest in teaching methods taught by teachers. There are various factors that cause student lacks of interest in teaching session taught by the teacher, among them is that the teacher is not well versed with the subject taught, the teacher only teaches theoretically, the teacher is not good at handling or using teaching aids (BBM), negative attitude towards subjects (students dislike subjects taught by teachers), less knowledgeable teachers and boring teachers. Therefore, there are various types of jokes that teachers need to learn to enhance effective teaching and learning inside the classroom.

\section{Literature Review}

Fun learning approach is known as entertaining teaching approach or jokes (Tay, 2015). Jokes are fun learning and 
teaching approaches (PdP) for students because they contain funny elements, philanthropic, aesthetic elements, traditional music games, acting and so on. Joke is an activity that has no adverse effect on humans if it is used in a controlled and ethical way. Jokes can be categorized into seven types that are funny stories, funny quips, jokes, professional jokes, teases, cartoons and riddles (Bryant, Comisky, Crane \& Zillman (1980); Torok, McMorris \& Lin (2006). These types of jokes are considered to generally have a positive impact in the classroom. They also found four non-tendentious jokes such as mockery, obscene jokes, ethnic related jokes and aggressive jokes or hostile humor. This kind of joke is found to have a negative impact on teaching and learning. Some types of jokes are considered by teachers and students as inappropriate, while the rest are interpreted differently depending on the source and recipients of the message. Furthermore, according to Wanzer, Frymier, Wojtaszczyk and Smith (2006) there are suitable jokes and inappropriate jokes that can be applied by the teacher. The study unravels four main categories of appropriate jokes that are related to content, which are not related to content, self-disparaging humor, and unplanned jokes. Meanwhile, inappropriate jokes can also be divided into four main categories that are offensive humor, degrading the students, debase others and self-disparaging humor.

According to a study conducted by Shaffe et al. (2011) and Tay (2015), jokes can affect students' academic achievement. In addition, jokes are also one of the methods for students to interact with each other. The joke elements applied in the PdP process can also create a fun learning atmosphere among students. Fun learning can indirectly improve the performance of teacher's in the classroom and improve student's academic achievement. Therefore, teachers must be creative in applying jokes in the classroom to attract students to learn. This is because effective teaching can be assessed through the variety of materials and techniques used during teaching (Yahya, 2012). According to studies from Miura and Jones (2005) and Friedman et al. (2002), stated that jokes is one of the teaching aids that can gain attention of students when they are in the classroom and help the PdP process to run smoothly. Jokes can provide entertainment, increase concentration, reduce stress, increase motivation, reduce boredom and relax the mind. Teachers can attract attention of students with negative behavior in learning by applying jokes in the classroom. Indirectly, students will become closer with their teachers or tutors. Additionally, the joke elements used in the classroom also enhances the relationship between teachers and students and increases the level of communication between students and teachers. According to a study by Malikow (2007) student loves humorous teachers. However, many teachers did not succeed in applying the joke elements during their time in the classroom.

Next, Jana et al. (2011) states that the use of joke elements during $\mathrm{PdP}$ is able to improve the student's memory level towards the lessons learned. In addition, individuals with a sense of humor have the advantage to delight others as compared to those who have no such advantage. This is because jokes can also reduce one's stress. The importance of jokes in tackling stress is in line with the study conducted by Duncan, Smelter and Leap (1990) and Abdul Ghani, Abd. Rahman and Abd. Rashid (2007) that jokes play a role in reducing stress and allows one to deal with boredom. Therefore, this study was conducted to identify the types of jokes applied and the frequency of using joke elements by teachers in the classroom. In addition, this study was also conducted to identify the involvement of students in the classroom if the jokes were applied and the relationship between the frequency of using joke elements and the involvement of students inside the classroom.

\section{The relationship between Joke Frequency and Students' Involvement in Classroom}

According to Roswati, Radhiah, Noor Asliza and Roslina (2017) in their studies related to the use of joke elements during the tour of Japanese tourists visiting Malaysia, it was found that the application of joke elements in tourism also had a positive impact. This study uses systematic observation method of audio visual recording and observation to obtain data on tour guide's interaction with tourists from Japan. As a result of the observation, researchers found that the joke elements that the tour guides employed during the visit created a more relaxed tour atmosphere and it is quicker for the group members to become friendlier. Therefore, the joke element is also a positive thing that can be applied in learning and teaching so that students are more focused (Brandon et al., 2017), dare to ask questions, and easily be friendly with teachers and friends. According to Lore, Peter and Mieke (2017), the application of jokes during the learning and teaching process (pdp) will strengthen or weaken the interaction between teacher and students in the classroom.

Their study using ethnographic methods in Belgium found that the teacher's function in applying jokes was to uplift pdp while jokes to students are a way in expressing to teachers and schools. Instructional Humor Processing Theory-IHPT is a theory introduced by Melissa, Ann, and Jeffrey (2010) combined results from the Incongruity-Resolution Theory, Disposition Theory, and the Elaboration Likelihood Model (ELM) of Persuasion. This theory is intended to identify reasons for not all types of jokes are appropriate to be used inside the classroom in improving student's achievement. A preliminary study was conducted on 378 pupils and the findings revealed that only jokes related to education can positively be related in improving the students' achievement in the academic.

In addition, Ji-yeon, Joo-yong and Jeeyon (2018) have also conducted studies on joke elements in improving South Korean student's confidence. A total of 23 students who are in phase 6 were involved in The Optimism and Humor Training Program (OHTP) for eight weeks. Upon completion of the program, researchers found that these students were more optimistic and more interested in attending school. In addition to improving confidence, jokes are also capable of strengthening one's resilience. This is in line with the study conducted by Brandi, Sean and Melanie (2016) that joke can reduce stress and enables someone to control their emotions. In addition to enhancing students 'interest in the subject, jokes are also able to improve students' academic achievement if properly implemented (Smith \& Wortley, 2017; Moshe \& Nancy, 2017) as well as enhance student's motivation(Sam, 2017). In addition, jokes not only can make someone happy and reduce one's stress, even in a study by Jennifer (2017) found that jokes are capable of enhancing individual's imagination, especially the children and are capable of expressing empathy for others. Mohammad Ali (2018), also believes that jokes helps a person to have a positive attitude. In addition, jokes can also strengthen bonds between family and friends (Smith \& Wortley, 2017) and it helps in having a higher otherworldliness. Jennifer (2017) also emphasized that teachers need to play an important role in applying jokes among children. San, Darrin and Alan (2017) had also conducted a study on the effect of jokes on the direct ability of students to transfer or store information obtained in the lessons learned. This study uses experimental methods to look at the 
effects of student's achievement in lesson if the joke element is applied in pdp. The findings revealed that students exposed to humour approaches in pdp obtained weak results in the two tests given. Therefore, it can be concluded that the use of humour element in the classroom during pdp should be wellmonitored by teachers because excessive jokes will bring down a student's academic achievement.

\section{Research Conceptual Framework}

In this study, researcher refers to Incongruity Theory which is a theory related to humour. According to Berlyne in Frymier, Wanzer, \& Wojtaszczyk (2008), Incongruity Theory has two phases. The first phase is when a message or stimulus is incorrectly placed or not in its suitable place. This message should initially be identified and translated by the recipient as a joke or a joke to be interpreted as a laughing matter. Meanwhile, for the second phase, when a humourous message is processed and evaluated as ludicrous, then a content of the incongruity message needs to be identified and make sense to the recipient. Therefore, for a joke message to be processed and evaluated as ludicrous, then the contents of the incongruity message need to be identified and reasonable to the recipient. If the incongruity is too awkward and absurd or too complex, the recipient will not feel the message as funny. In addition, the Social Learning Theory by Bandura and the Humanism Learning Theory founded by Abraham, Carl and Malcolm were found to be related to humour practices that could create an effective learning situation. Gurtler (2002) relates the theory by Bandura to the "burnt-out" syndrome inherent to the teacher. According to him, the role of humour is to prevent burnt-out syndrome among teachers as well as to help improve student's achievement. Meanwhile, Humanism Theory emphasizes on the environment that supports learning to help the teaching and learning process. In Humanism Theory, learning is student centered and individual (personal) process.

Based on Figure 1, the conceptual framework of the study shows that the researcher uses Incongruity Theory that if the kind of joke practiced by the teacher in the classroom is appropriate then it is interpreted as something that is tickling but, if the joke used is unreasonable then the message is not funny. Next, Social Learning Theory is applied in the conceptual framework of this study where the use of joke elements can reduce the stress among students and teachers inside the classroom. Meanwhile, Humanism Theory emphasizes on the environment that supports learning to help the teaching and learning process. In Humanism Theory, learning is student-centered and based on individual. Conducive environment that encourages learning is needed for affective and cognitive development. In this case, practicing joke or kecindan can help create a learning environment that helps support the effective and cognitive developments of the student.

Independent Variables

Dependent Variables

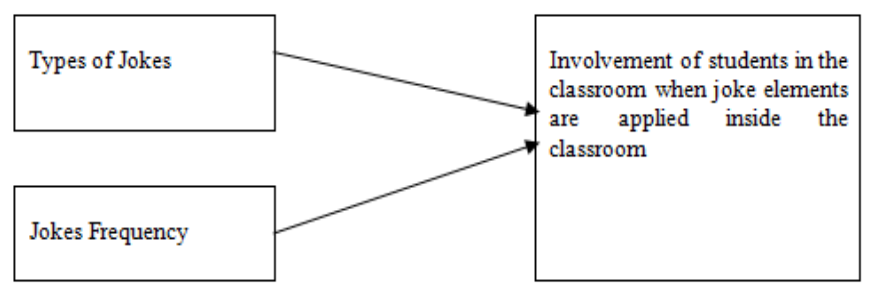

Figure 1. Research Conceptual Framework (Theory Incongruity, Social Learning Theory

\section{by Bandura and Humanism Teaching Theory)}

\section{Methodology}

In this study, the research type used is a quantitative survey. Data were collected using a set of questionnaires consisting of four sections. The data collected were used to examine the functionality of the item, the validity and reliability of the research instrument through the data of the item obtained. According to Lim (2007), quantitative research is a study that mainly uses statistical analysis, behavioral and phenomena study, very objective and collecting numerical data. In addition, according to Sekaran and Bougie (2012), quantitative research methods are a research method that involves descriptive, correlation, or causal-experimental data analysis. In this study, researchers selected a descriptive type cross sectional survey study involving descriptive analysis and inferential analysis.

The population of the study involved secondary school teachers in Muallim District. Study sample required was 300 people and selected using simple random sampling. Therefore, 300 sets of questionnaires have been distributed to ensure that the required amount in this study can be met and that only respondents who complete the questionnaire are sampled. However, only 269 sets of questionnaires have been collected $(89.67 \%)$.

\section{A Pilot Study}

Hair et al. (2010) argued that 5 - 30 respondents were required in pilot studies while Cooper and Schindler (2011) stated that the respondents required for pilot study were $25-100$ persons. Therefore, the researcher has determined that the number of respondents to be involved in this pilot study is 30 teachers from Sekolah Menengah Kebangsaan Dato Zulkifli Muhammad. Respondents involved in the pilot study are no longer involved in the actual study. Based on Table 3.4, the coefficient of $\alpha$ shows the reliability value of the three constructs, that are the joke, the kind of joke, and the involvement of students in the classroom is approaching 1.0. There are 10 items for the joke type constructs and the coefficient value of $\alpha$ shows 0.76 while the joke element item is 7 items and the value of the $\alpha$ coefficient shown is 0.71 . For the construct of student participation in the classroom there are 10 items of coefficient value $\alpha$ showing the value of 0.93 . In conclusion, based on Hair et al. (2010), the level of reliability shown for the constructs of joke elements and joke types is good while the level of reliability of the student involvement construct in the classroom is the best. In addition, the analysis also found that no sub-constructs showing weak values. Therefore, none of the items dropped from this instrument and this instrument is reliable and is used for its in-depth study in measuring student engagement when joke elements are applied in the classroom.

\section{Data Analysis}

The data obtained through the questionnaire were analyzed using descriptive statistical analysis and inferential statistics. Descriptive statistics illustrate the tendency of centralized mean, frequency and percentage. Meanwhile, inferential statistics explain the correlation between the two variables. Both of these statistics use the IBM SPSS version 22 software. Based on Table 3.16, descriptive analysis is used to analyze the respondents' demographic profiles and to answer the questions 1, 2, and 3 of the study by looking at the frequency (n), percentage $(\%)$, mean, and standard deviation. While the inference analysis involves the objective of study 4 , that is by 
looking at the Pearson's correlation coefficient (r). The respondents' demographic part, are discussed according to gender, age, race, academic qualifications, service period, and the subjects currently being taught.

\section{Research Findings and Discussion}

\section{The type of joke or jest element used in the classroom}

Table 4.1 shows that a total of 92 teachers in Muallim District (34.20\%) agree with the "I use joke elements while teaching in classrooms such as jokes, cynics, funny face expressions and funny stories." Then, followed by the item "I told a healthy activity in a joke", a total of 63 teachers (23.40\%) agreed on this item. There were 253 teachers $(94.10 \%)$ who strongly disagreed with the item "I made pornographic jokes" and 228 teachers strongly disagreed $(84.80 \%)$ with items "I use a language that is abusive in joke". A total of 161 teachers $(59.90 \%)$ also strongly disagree with the item "I make ethnic and racial jokes". Items that are highly disagreed by teachers in Muallim District are items that show negative activities that should be avoided in the classroom to prevent students from being influenced by negative elements.

\section{Schedule 1 Type of Joke Element Used in the Classroom}

\begin{tabular}{|c|c|c|c|c|c|c|c|c|}
\hline \multirow{3}{*}{ Item } & \multicolumn{8}{|c|}{ Scale } \\
\hline & \multicolumn{2}{|c|}{$\begin{array}{l}\text { Strongly } \\
\text { Disagree }\end{array}$} & \multicolumn{2}{|c|}{ Disagree } & \multicolumn{2}{|c|}{ Agree } & \multicolumn{2}{|c|}{$\begin{array}{l}\text { Strongly } \\
\text { Agree }\end{array}$} \\
\hline & $\mathrm{n}$ & $\%$ & $\mathrm{n}$ & $\%$ & $\mathrm{n}$ & $\%$ & $\mathrm{n}$ & $\%$ \\
\hline $\begin{array}{l}\text { I use joke elements while teaching in classrooms } \\
\text { such as jokes, cynics, funny face expressions and } \\
\text { funny stories. }\end{array}$ & 1 & 0.40 & 18 & 6.70 & 158 & 58.70 & 92 & 34.20 \\
\hline $\begin{array}{l}\text { I use a cynical syllabus regarding titles in general } \\
\text { (not related to subjects) }\end{array}$ & 23 & 8.60 & 87 & 32.30 & 123 & 45.70 & 36 & 13.40 \\
\hline I use a language that is abusive in jokes. & 228 & 84.80 & 32 & 11.90 & 9 & 3.30 & 0 & 0.00 \\
\hline I made pornographic jokes. & 253 & 94.10 & 15 & 5.60 & 1 & 0.4 & 0 & 0.00 \\
\hline I recite healthy activities in a joke. & 4 & 1.50 & 17 & 6.30 & 185 & 68.80 & 63 & 23.40 \\
\hline I use cartoon images as lesson content. & 27 & 10.0 & 99 & 36.80 & 125 & 46.50 & 18 & 6.70 \\
\hline $\begin{array}{l}\text { I use puzzle questions while making reinforcement } \\
\text { training. }\end{array}$ & 31 & 11.5 & 103 & 38.30 & 111 & 41.30 & 24 & 8.90 \\
\hline I make ethnic and racial jokes. & 161 & 59.90 & 61 & 22.70 & 45 & 16.70 & 2 & 0.70 \\
\hline I provide training that focuses on puzzles. & 44 & 16.40 & 137 & 50.90 & 81 & 30.10 & 7 & 2.60 \\
\hline $\begin{array}{l}\text { I use funny media materials while teaching the use } \\
\text { of cartoons or comics. }\end{array}$ & 27 & 10.0 & 87 & 32.30 & 138 & 51.30 & 17 & 6.30 \\
\hline
\end{tabular}

Based on the findings of the study, researchers found that respondents were using more joke types such as jests, cynics, funny facial expressions, and funny stories while in the classroom. The type of joke used by the majority of respondents recorded the highest mean value compared to other items. Based on the item being asked, the respondents stated they used the type of joke to create a fun learning atmosphere. According to Yahya (2012), associating humour with fun can cause a person to get excited to hear it. Application of joke elements not only can be applied in the classroom but joke can also be implemented in other areas. According to Roswati, Radhiah, Noor Asliza, and Roslina (2017), the joke applied in tourism makes tourists focus on the information presented and this can also be proven in the field of education that jokes not only make the students happy (Yahya, 2012) to learn, but also attracts students' attention and interest in focusing on the information provided by lecturers and makes the learning environment becomes more relaxed and friendly. The findings of this study are supported by Abdul Ghani and Abd.Rahman (2009) that stated teachers need to use language that is able to express funny feelings and graphics usage that can give the students a pleasant atmosphere.

\section{What is joke frequency used by teachers in the classroom?}

Table 2 shows the frequency level distribution of joke element used by teachers inside the classroom in answering the questions in the first study. The analysis found that this construct was at a moderate level $(\mathrm{n}=164$, percentage $=$ $61.00 \%$ ). It can be concluded that not all teachers in Muallim District apply jokes in the classroom in enhancing students' interest in the lesson.

Table 2 Frequency Level Distribution of Joke Element Used by Teachers in the Classroom

\begin{tabular}{llll}
\hline Variable & Level & Frequency $(\mathrm{n}=269)$ & Percentage $(\%)$ \\
& & & \\
\hline Joke Frequency & Low & 17 & 6.30 \\
& Moderate & 164 & 61.00 \\
& High & 88 & 32.70 \\
\hline
\end{tabular}

The researchers presented 7 items relating to the frequency of a respondent using jokes in the classroom. In this study, researchers found that the frequency of teachers using jokes in the classroom that recorded the highest mean value is for the item "I like to use electronic media such as computers to provide fun teaching and learning materials". This analysis is supported by James (2001), that rule of thumb for the teacher should include three to five jokes related to the content of the 
lesson for every 50 minutes of learning time. Whereas the lowest mean value is recorded on the item "I use studentcentered learning techniques such as acting, role playing and singing". To answer the doubts of study 2 , the analysis found that there is a moderate level of joke frequency used by teachers in the classroom. However, this study can be proven through the study conducted by Abdul Rasid and Hasmah (2013) that teachers are showing a positive interest in developing pedagogical skills that they have and they also showing an interest in producing exciting teaching aids.

Additionally, teachers are also keen in producing instructional materials using electronic media and jokes in the classroom to enhance students' interest in learning (Abdul Rasid and Hasmah, 2013). Furthermore, this study also supports the study conducted by Tay (2015); Smith and Wortley (2017); Moshe and Nancy (2017) which is the repetitive of using joke elements can improve the performance of teacher in teaching and students' learning in the classroom as well as to enhance students' motivation (Sam, 2017). However, studies by San, Darrin, and Alan (2017) disagreed that the frequency of joke usage is able to improve students' academic achievement as their research found that students that were exposed to jokes approach in pdp obtained weaker results in two tests that were given. Miura and Jones (2005) also argue that jokes cannot be used arbitrarily because they can cause negative things among students.

\section{What is a student involvement when joke element is applied in the classroom?}

Table 3 shows that a total of 115 teachers $(38.50 \%)$ strongly agree with the item "students are at ease with teacher when talking or interacting" followed by item "students actively involved when teachers conduct activities in classroom", a total of $108(36.10 \%)$ people strongly agreed with this item. Furthermore, for items "students are more confident to express their opinions or ideas related to the subjects taught by teachers during the discussion session" a total of 106 teachers $(35.50 \%)$ strongly agree with this item. However, there were 11 teachers $(3.70 \%)$ who strongly disagreed with the item "formality level between teacher and students are similar to friends or students considering a teacher as a friend". This item is strongly disagreed because it can lead these students to become disrespectful to the teacher and so on.

Table 3 Distribution of Student Involvement when Joke Element is Applied in Classroom

\begin{tabular}{|c|c|c|c|c|c|c|c|c|}
\hline \multirow[t]{3}{*}{ Item } & \multicolumn{8}{|c|}{ Scale } \\
\hline & \multicolumn{2}{|c|}{$\begin{array}{l}\text { Strongly } \\
\text { Disagree }\end{array}$} & \multicolumn{2}{|c|}{ Disagree } & \multicolumn{2}{|c|}{ Agree } & \multicolumn{2}{|c|}{ Strongly Agree } \\
\hline & $\mathrm{n}$ & $\%$ & $\mathrm{n}$ & $\%$ & $\mathrm{n}$ & $\%$ & $\mathrm{n}$ & $\%$ \\
\hline $\begin{array}{l}\text { Students are more focused on the lesson } \\
\text { contents when jokes are applied. }\end{array}$ & 1 & 0.30 & 17 & 5.70 & 177 & 59.20 & 104 & 34.80 \\
\hline $\begin{array}{l}\text { Students can answer questions quickly } \\
\text { when teacher ask questions. }\end{array}$ & 1 & 0.30 & 23 & 7.70 & 186 & 62.20 & 89 & 29.80 \\
\hline $\begin{array}{l}\text { Students can easily remember the lesson } \\
\text { contents being taught when questioned by } \\
\text { teacher. }\end{array}$ & 1 & 0.30 & 24 & 8.00 & 175 & 58.50 & 99 & 33.10 \\
\hline $\begin{array}{l}\text { Students are confident to see teacher } \\
\text { asking for further clarification on what } \\
\text { they don't understand. }\end{array}$ & 3 & 1.00 & 18 & 6.00 & 181 & 60.50 & 97 & 32.40 \\
\hline $\begin{array}{l}\text { Students are more confident to express } \\
\text { opinions or ideas related to the subjects } \\
\text { taught by the teacher during the discussion } \\
\text { session. }\end{array}$ & 2 & 0.70 & 10 & 3.30 & 181 & 60.50 & 106 & 35.50 \\
\hline $\begin{array}{l}\text { Students actively involved when teachers } \\
\text { conduct activities in classroom. }\end{array}$ & 1 & 0.30 & 12 & 4.00 & 178 & 59.50 & 108 & 36.10 \\
\hline $\begin{array}{l}\text { Formality level between teacher and } \\
\text { students are similar to friends or students } \\
\text { considering the teacher as a friend. }\end{array}$ & 11 & 3.70 & 46 & 15.40 & 167 & 55.90 & 75 & 25.10 \\
\hline $\begin{array}{l}\text { Students can create a good rapport with } \\
\text { teachers. }\end{array}$ & 2 & 0.70 & 11 & 3.70 & 182 & 60.90 & 104 & 34.80 \\
\hline $\begin{array}{l}\text { Students are at ease with teacher when } \\
\text { talking and interacting. }\end{array}$ & 2 & 0.70 & 8 & 2.70 & 174 & 58.20 & 115 & 38.50 \\
\hline $\begin{array}{l}\text { Jokes increase students understanding } \\
\text { towards subjects. }\end{array}$ & 5 & 1.70 & 23 & 7.70 & 166 & 55.50 & 105 & 35.10 \\
\hline
\end{tabular}

Discussion for the third objective is to examine the students' involvement in the classroom whether active or not if joke elements are applied during the learning and teaching process. Based on the findings of the study, overall, researchers find that if a teacher applies an element of jokes inside the classroom, students will be at ease with the teacher and the students will become more participative to be involved when the teacher conducts activities in the classroom. This study is consistent with findings by Brandon et al. (2017) students will become more focused, at ease to ask questions, and be friendly with teachers and colleagues. However, there is a limit to friendly relationship between students and teachers because some teachers in the Muallim District are in the view that the level of formalities between teachers and students are like friends or student taking teacher as a friend will cause students giving less respect to their teachers. The analysis also found that this item shows the lowest mean of which the majority of teachers disagreed if the joke element is applied causes the student to lose their respect for the teacher. Unlike Lore, Peter, and Mieke (2017), they argued that the use of joke elements in the classroom can cause students to be discreet, losing focus and academically deteriorated. It can be concluded that the 
applied joke elements can influence the level of student involvement in the classroom. Excessive joke elements can cause students to lose focus in learning and if jokes are well implemented, it can help in achieving good academic accomplishment and helping students to be highly spirited.

Is there a relationship between joke frequency and the involvement of students when the joke element is applied inside the classroom?
Table 4 shows the results of correlation analysis to answer the hypothesis of this study. Based on the analysis, it is found that there is a moderately significant relationship between the joke frequency and the students' involvement when joke element is applied inside the classroom which is the coefficient of $r$ shown is $r=0.42, p<0.05$.

Table 4 Analysis of Correlation Test between Joke Frequency and Student Involvement when the Joke Element is applied in the Classroom

\begin{tabular}{llllll}
\hline & \multicolumn{4}{l}{ Students' Involvement when Joke Element is Applied inside the Classroom $(\mathrm{n}=269)$} \\
\cline { 2 - 5 } & IBM SPSS & \multicolumn{2}{c}{ Relationship Interpretation } & Hypothesis $\left(\mathrm{H}_{0}\right)$ \\
\hline Frequency of & $\mathrm{r}$ & & 0.42 & \multirow{2}{*}{ Moderate } & Rejected \\
Humor Element & & Sig. (2-tailed) & 0.00 & & \\
\hline
\end{tabular}

Correlation is significant at the 0.05 level (2-tailed)

In this research, the hypothesis of the study is that there is no relationship between the joke frequencies with the students' involvement when joke elements are applied inside the classroom. The study found that this hypothesis should be rejected. The analysis found that there was a relationship between these two variables, but the relationship shown was moderate. In addition, the findings of this study support the study conducted by Norul Haida (2011) that there is a strong relationship between the teaching style and the application of joke elements as a stimulant in the learning situation for Bahasa Melayu. Additionally, joke element is also one of the factors that can contribute to student engagement in the classroom and produce many teachers that are creative and critical in handling learning and teaching. This is proven by the analysis that has been done and found that the teachers' skills in handling electronic media are able to produce fun teaching and learning materials. This study is also supported by Shaffe, Ramli, Roselan, Sahandri, and Mokhtar (2011),that stated that the application of jokes in the classroom can control the atmosphere of the classroom to be more harmonious and enhance the student's focus in learning. In addition, the findings of the study are also of the same opinion with Abdul Rasid and Hasmah (2013) that the use of multimedia can create fun learning experience inside the classroom.

Additionally, the relationship between the joke frequency and students' involvement inside the classroom can improve the level of student-centered learning, relieve stress for students during the learning and teaching process, improving the comfortable learning environment, and attracting the attention and willingness of students to learn (Abdul Rasid and Hasmah, 2013). Also according to Abdul Rasid and Hasmah (2013), joke frequency not only contributes to positive impacts to students, but also improves the teaching performance of a teacher, improves pedagogical skills of a teacher, and helps to create creative and innovative ideas and make the teachers eager to deliver their knowledge (Abdul Rasid and Hasmah, 2013).

\section{Conclusion}

Overall, this study can help researchers to conclude the kind of jokes that need to be applied in the classroom as it affects the involvement of students in the classroom. In this regard, teachers particularly play an important role in enhancing students' involvement inside classroom in developing country's education. Based on the analysis and discussion presented, the researcher found that the kind of joke used by the teacher plays an important role in gaining students' participation inside the classroom. Teachers must know how to make jokes to create fun learning ambiance. Other than that, teachers should also choose an appropriate type of jokes to attract students' interest in the learning session. Next, for item on jokes frequency, a teacher must be alert towards the classroom environment. Teachers need not to make jokes throughout the learning process and the whole time while teaching because excessive joke is also said to be detrimental to learning time. Teachers should use humor at least 3-4 times during the 50-minute learning process as according to Yahya (2012).

\section{Acknowledgement}

I would like to express my deepest gratitude to the Universiti Pendidikan Sultan Idris, Tanjong Malim Perak, Malaysia, for providing the financial assistance needed to complete this research under the University's Research Incentive Grant Scheme (2017-0224-107-01) years 2017 to 2018.

\section{References}

[1] Abang Othman, A. E. I., Sam, H. K., \& Nordin, Z. S. (2005). Computer Self-Efficacy, Computer Anxiety, and Attitudes toward the Internet: A Study among Undergraduates in Unimas. Educational Technology \& Society, 8(4), 205-219.

[2] Abdullah, A. G., Abdul Aziz, A. R., Ahmad, \& A. Ahmad M. Z. (2005). Kesan Efikasi Kendiri Guru Sejarah Terhadap Amalan Pengajaran Berbantukan Teknologi Maklmumat dan Komunikasi (ICT). Jurnal Penyelidikan Pendidikan.

[3] Abdullah, M. C., Cheong, L. S., Elias, H., Mahyuddin, R., Muhammad, F. M., \& Noordin, N. (2011). The Relationship between Students' Self-Efficacy and Their English Language Achievement. Journal of Educational Psychology and Counseling, 2,145-174.

[4] Abdullah, M. C., Elias, Habibibah, Mahyuddin, Rahil, Roslan, Samsilah, Noororeen \& Noodin. (2009). Selfefficacy Beliefs of At-Risk Students in Malaysian Secondary Schools. The International Journal of Learning, 16(4), 201-210.

[5] Abesha, A. G. (2012). Effects of Parenting Styles. Academic Self-Efficacy and Achievement Motivation on the Academic Achievement of University Students in Ethiopia. Unpublished thesis. Retrieved 25/5/2012 from http://ro.ecu.edu.au/cgi/viewcontent.cgi?article=1461\&co ntext=theses. 
[6] Abu-Tineh, A. M., Khasawneh, S. A., \& Khalaileh, H. A. (2011). Teacher Self-efficacy and Classroom Management Styles in Jordanian Schools. Management in Education, 25(4), 175-181.

[7] Abd-Elmotaleb, M. \& Saha, S. K. (2013). The Role of Academic Self-Efficacy as a Mediator Variable between Perceived Academic Climate and Academic Performance. Journal of Education and Learning, 2(3), 117-129.

[8] Allen. J. P., Chango, J. Szwedo, D. Schad, M. \& Marston, E. (2012). Predictors of Susceptibility to Peer Influence Regarding Substance Use in Adolescence. Child Development, 83(1), 337-350.

[9] Ambo, N. F., \& Lebar, O. (2012). Hubungan Gaya Pembelajaran, Efikasi Kendiri Dengan Pencapaian Matematik Pelajar Cina. Retrieved 14/5/2012 from http://www.ukm.my/fsskconf/index.php/icosh/icosh2012/ paper/view/76.

[10] Ary, D. V. Duncan, T. E. Duncan, S. H. \& Hops, H. (1999). Problem Behavior: The Influence of Parents and Peers. Behaviour Research and Therapy, 37, 217-230.

[11] Ashley D.Rittmayer, M. E. B. (2008). Overview: SelfEfficacy in STEM, SWE-AWE-CA, 1-12. Retrieved 15/5/2013 from http://www.aweonline.org.

[12] Ayotola, A., \& Adedeji, T. (2009). The Relationship between Mathematics Self-Efficacy and Achievement in Mathematics. Procedia-Social and Behavioral Sciences, 1(1), 953-957.

[13]Bandura, A. (1977) Towards a Unifying Theory of Behavioral Change. Psychological Review, 84(22), 191215.

[14] Bandura, A. (1993) Perceived Self-Efficacy in Cognitive Development and Functioning. Educational Psychologist, 28(20), 117-148.

[15]Bandura, A. (1997). Self-efficacy: The Exercise of Control. $\quad$ Retrieved 20/5/2013 from http://interventiondesign.eu/?q=node/25.

[16] Berita Harian Online. (2010, Jun 29). Kadar Jenayah Babit Pelajar, Kanak-Kanak Meningkat Retrieved from http://www.bharian.com.my/bharian/articles/-

Kadarjenayahbabitpelajar_kanakkanakmeningkat/Article.

[17] Berita Harian Online. (2010, December 28). Masalah Salah Laku Disiplin Pelajar Masih Terkawal Retrieved from http://www.bharian.com.my/bharian/articles/Masalahsalahlakudisiplinpelajarmasihterkawal/Article/.

[18] Britner, S. L., \& Pajares, F. (2006). Sources of Science Self-Efficacy Beliefs of Middle School Students. Journal of Research in Science Teaching, 43(5), 485-499.

[19] Brosnan, M. J. (1998). The Impact of Computer Anxiety and Self-Efficacy upon Performance. Journal of Computer Assistance Learning, 14(3), 223-234.

[20] Brown, B., Hansen, S. \& Taipjutorus, W. (2011). Improving Learners' Self-efficacy in a Learner-controlled Online Learning Environment: A Correlational Study, 2004-2008. Retrieved from http://www.ascilite.org.au/conferences/wellington12/2012/images/custom/taipjutorus,_widchaporn__improving.pdf.

[21] Cheong, F., Cheong, C., \& Weng, F. (2009). IT Education in Taiwan: Relationship between Self-efficacy and Academic Integration among Students', Proceedings of International Conference on Innovation in Teaching and Management of Higher Education (ICITM 09), Shah Alam, Selangor, Malaysia 21-23.

[22] Choy, J. L. F. And Loo, C. W. (2013). Sources of SelfEfficacy Influencing Academic Performance of
Engineering Students. American Journal of Educational Research, 1(3), 86-92.

[23] Dodge, K. A., \& Gonzalez, N., (2010). Family and Peer Influences on Adolescent Behavior Risk Taking. Unpublished article. Retrieved 24/5/2013 from http://www.iom.edu/ /media/Files/Activity\%20Files/Chil dren/AdolescenceWS/Commissioned\%20Papers/dodge g onzales_paper.pdf.

[24] Espendhadet, T. J., Lynch, S. M., and Zajacova, A. (2005). Self-Efficacy, Stress, and Academic Success in College. Research in Higher Education, 46(6).

[25]Fetrman, C. L., \& Primack. B. A. (2009). Elementary Students' Self-Efficacy Scale Development and Validation Focused on Student Learning, Peer Relations, and Resisting Drug Use. Journal Drug Education, 39(1), 23-38.

[26] Giallo, R., \& Little, E. (2003). Classroom Behaviour Problems: The Relationship between Preparedness, Classroom Experiences, and Self-efficacy in Graduate and Student Teachers, 3, 21-34.

[27] Ismail Kailani \& Khairuzaman Ismail. (2010). Mengenal Pasti Faktor-Faktor Yang Menyebabkan Pelajar Kurang Cemerlang Dalam Mata Pelajaran Sains. Satu Kajian Tinjauan Di Sebuah Sekolah Menengah Luar Bandar Fakulti Pendidikan. Universiti Teknologi Malaysia.

[28] Ismail, A. M., Stapa, Z., Othman, M. Y. \& Yaacob. M, (2012). Islam dalam Pendidikan dan Hubungannya dengan Pembentukan Jati Diri Bangsa Melayu di Malaysia. Jurnal Hadhari, Special edition, 37-50.

[29] Kira, D. \& Saade, R. G. (2009). Computer Anxiety in ELearning: The Effect of Computer Self-efficacy. Journal of Information's Technology Education, 8, 177-191.

[30] Kirk, K. (2013), SERC, Self-Efficacy: Helping Students Believe in Themselves. Retrieved 20 May 2013, from http://serc.carleton.edu/NAGTWorkshops/affective/efficacy.html.

[31] Lewandawski, K. H. L. (2005). A Study of the Relationship of Teachers' Self-efficacy and The Impact of Leadership and Professional Development. Retrieved $6 / 7 / 2013$ from http://dspace.iup.edu/bitstream/handle/2069/17/Karen+He idi+Lewandowski.pdf;jsessionid=E6511A1887F167E55FC86 38FE82083C3? sequence $=1$.

[32] Lilley, J. L. Oberle, C. D. \& Thompson, J. G. (2011). Self-Efficacy and Learning in Sorority and Fraternity Students. Journal of College Student Development, 52(6), 749-753.

[33] Margolish, H. (2005). Increasing Struggling Learners' Self-Efficacy: What Tutors Can Do and Say Mentoring and Tutoring, 13(2), 221-238.

[34] Margolish, H., \& Mccabe, P. P. (2006). Improving SelfEfficacyand Motivation: What to Do, What to Say. Intervention in School and Clinic, 4(41), 218-227.

[35] McKenzie, K. (1999). Correlation between Self-efficacy and Self-esteem in Students. Retrieved 18/9/2013 from http://www2.uwstout.edu/content/lib/thesis/1999/1999mckenzie.pdf.

[36] Md. Sawari, S. S., Ghazali, M. A., \& Mansor, N. (2014). Exploring Level of Community Self-Efficacy among Religious Schools Students: A Study in Ledang, Johor. International Graduate Conference on Engineering, Science and Humanities 2014. Universiti Teknologi Malaysia, Johor Bahru, Malaysia 19-21 August 2014. DOI: $10.13140 / 2.1 .2694 .8800$.

[37] Md. Sawari, S. S., \& Ghazali, M. A. (2014). Learning 
Efficacy between Religious and Public School Students: A Comparative Study. Social Sciences Postgraduate International Seminar, At Universiti Sains Malaysia. DOI: $10.13140 / 2.1 .4193 .5041$.

[38] Md. Sawari, S. S., Kazeem, B. \& Mansor, N. (2013). Investigating the Correlationship between Level of SelfEfficacy and Gender. International Journal of Education Research, 1(12): 1-10.

[39] Moree, B. (2007). The Relationship among Self-efficacy, Negative, Self-statements, and School Anxiety in Children: A Mediations. Unpublished Thesis. Clemson University. Retrieved 25/5/2013 from http://etd.1su.edu/docs/available/etd-06082010124222/unrestricted-/moreethesis.pdf.

[40] Onyeizugbo, E. U. (2010). Self-Efficacy and Test Anxiety as Correlates of Academic Performance. International Research Journals, 1, 477-480.

[41] Pajares, F. (2002). Overview of Social Cognitive Theory and Of Self-Efficacy. Retrieved Jun 21, 2014, from http://people.wku.edu/richard.miller/banduratheory.pdf.

[42] Pajares, F. (2005). Self-Efficacy during Childhood and Adolescence. Implications to Teachers and Parents. SelfEfficacy Beliefs of Adolescents, 15, 339-367.

[43] Pihie, Z. A. L., Kui, T. L., Fooi, F. S., Kasa, Z., \& Uli, J. (n.d.). Hubungan kepimpinan Transformational Pengetua dengan Efikasi Kendiri Guru. Retrieved from http://www.medc.com.my/medc/journals/vol2/3.\%20-

Hubungan \%20Kepemimpinan\%20Transformational\%20P engetua\%20dengan\%20Efika.pdf.

[44] Ragin. (2010). Constructing Social Research. The Unity and Diversity of Method. Retrieved 11/7/2013 from http://uwhonors2010.virtualknowledgestudio-.nl/wpcontent/uploads/reading/Ragin.pdf.

[45] Redmond, B. F., \& Willis, A. R. (2013). Self-Effiacy and Social Cognitive Theories. Retrieved 14/5/2013 from https://wikispaces.psu.edu/display/PSYCH484/7-.+Self Efficacy+and-+Social+Cognitive+Theories.

[46] Sanders, M. R., \& Woolley, M. L. (2005). The Relationship between Maternal Self-Efficacy and Parenting Practices: Implications for Parent Training. Child: Care, Health and Development, 31(1), 65-73.

[47] Schunk, D. H. (1991). Self-Efficacy and Academic Motivation. Educational Psychologist, 26, 207-231.

[48] Shkullaku, R. (2013). The Relationship between SelfEfficacy and Academic Performance in the Context of Gender among Albanian Students. European Academic Research, 1(4), 467-478.

[49] Walker, C. L. (2011). Correlational research. Journal of the Association of Paediatric Oncology Nurses, 6(1), 212. Retrieved 7/5/2013 from http://www.ncbi.nlm.nih.gov/pubmed/23451476.

[50] Yahaya, A. \& Latif, J. S. (2005). Membentuk Identiti Remaja. Pahang: PTS Publications and Distribution Sdn. Bhd.

[51] Yeşi̇lyurt, E. (2013). Academic Self-Efficacy Perceptions of Teacher Candidates. Mevlana International Journal of Education (MIJE), 3(1), 93-103.

[52]Zalika Adam, Faridah Kassim \& Mohamad Johdi Salleh. (2009). Memperkasakan Pendidikan Luar Bandar. Prosiding Persidangan Kebangsaan Pendidikan Luar Bandar 2009, 3-5 Februari 2009, Hotel Baverly, Kota Kinabalu, Sabah. Anjuran: Sekolah Pembangunan dan Pendidikan Sosial, University Malaysia Sabah.

[53]Zimmerman. B. J. \& Cleary. T. J. (2006). Adolescents'
Development of Personal Agency. The Role of Selfefficacy Beliefs and Self-Regulatory skill. Retrieved from http://www.uky.edu/ eushe2/Pajares/ZimmermanClearyA doEd5.pdf.

[54]Zubair, A. A. \& Md. Sawari, S. S. (2013). Spiritual and Psychological Health of International Islamic College Staffs. Asian Journal of Management Sciences \& Education, 3(1), 148-152 